\title{
KADAR ADIPONEKTIN SEBAGAI FAKTOR RISIKO PENEBALAN TUNIKA INTIMA MEDIA ARTERI KAROTIS
}

\author{
Hadi Juanda, ${ }^{1}$ Toni MA, ${ }^{1}$ Undang Ruhimat, ${ }^{2}$ Ernijati Suardi, ${ }^{1}$ \\ 'Subbagian Kardiovaskular Bagian IImu Penyakit Dalam Fakultas Kedokteran \\ Universitas Padjadjaran/Rumah Sakit Hasan Sadikin, Bandung \\ ${ }^{2}$ Bagian Radiologi Fakultas Kedokteran Universitas Padjadjaran/ \\ Rumah Sakit Hasan Sadikin Bandung
}

\begin{abstract}
ABSTRAK
Penyakit kardiovaskular masih merupakan masalah kesehatan dan penyebab kematian utama di negara maju dan berkembang walaupun telah dilakukan upaya pencegahan dan tata laksana yang baik. Pemeriksaan ultrasonografi (USG) sebagai evaluasi/diagnosis dini adanya aterosklerosis subklinis untuk memprediksi kejadian kardiovaskular di masa mendatang. Pemeriksaan carotid intima media thickness (CIMT) dapat memberikan gambaran adanya kerusakan/disfungsi pembuluh darah secara umum terutama pembuluh koroner jantung. Adiponektin mempunyai efek antiinflamasi dan antiaterogenik sehingga disimpulkan adiponektin bermanfaat karena mempunyai efek kardioprotektif. Walaupun demikian penelitian peranan adiponektin terhadap penebalan tunika intima media arteri karotis pada manusia masih terbatas dan hasil penelitian menemukan hasil yang berbeda. Untuk mengetahui peranan adiponektin sebagai faktor risiko terhadap penebalan tunika intima media arteri karotis dilakukan penelitian dengan rancangan kasus kelola. Subjek penelitian adalah penderita obesitas abdominal pria dan wanita dengan rentang usia 40-59 tahun yang telah diperiksa ketebalan tunika intima media arteri karotis dengan USG. Kriteria eksklusi adalah gagal jantung kongestif, penyakit jantung koroner, stroke, dan penderita yang menggunakan obat glukokortikoid. Didapatkan 40 subjek dengan penebalan tunika intima media arteri karotis (kasus) dan 40 subjek tanpa penebalan tunika intima media arteri karotis (kontrol). Pada kelompok kasus kadar adiponektin lebih rendah dibanding kelompok kontrol, yaitu yaitu $4,1 \mu \mathrm{g} / \mathrm{mL}$ (SB 1,7) berbanding $6,0 \mu \mathrm{g} / \mathrm{mL}(\mathrm{SB} 3,0)$. Hasil analisis statistik dengan uji chi square pada derajat kepercayaan 95\% (1,05-12,78), OR 3,67 dengan nilai $p=0,04$ menunjukkan bahwa adiponektin bersama dengan DM, hipertensi dan MetS secara bermakna merupakan faktor risiko untuk terjadinya penebalan tunika intima media arteri karotis. Pada penelitian ini didapatkan titik potong (cut-off point) kadar adiponektin sebesar 5,09 ug/dL dengan ROC 0,682, derajat kepercayaan 95\% (0,569-0,782), sensitivitas $77,5 \%$ dan spesifisitas 55,0\%. Dari penelitian ini dapat disimpulkan bahwa kadar adiponektin yang rendah $(<5,09 \mathrm{ug} / \mathrm{dL})$ merupakan faktor risiko untuk terjadinya penebalan tunika intima media arteri karotis.
\end{abstract}

Kata kunci: Adiponektin, penyakit kardiovaskular, CIMT

\section{ADIPONECTIN LEVEL AS A RISK FACTOR OF CAROTID ARTERY INTIMA- MEDIAL THICKENING}

\begin{abstract}
Cardiovascular diseases remain a major health problem and the leading cause of mortality both in industrialized and developing country, despite the improvement in its prevention and management. Ultrasonography (USG) can be used in the evaluation and early diagnosis of subclinical atherosclerosis to predict cardiovascular events in the future. Carotid intima-medial thickness (CIMT) is a surrogate of vascular dysfunction especially coronary vessels. Adiponectin has anti-inflammatory and anti-atherogenic properties, that is thought to be beneficial because of its cardioprotective effect. However the studies in the role of adiponectin in human is limited and earlier studies found conflicting results. To evaluate the role of adiponectin as a risk factor of carotid artery intima-medial thickening, we conducted this case-control study. The subjects were obese male and female between 40-59 years of age, who were evaluated by carotid artery intima-medial ultrasonography. Exclusion criteria were congestive heart failure, coronary heart disease, stroke and glucocorticoid treatment. Forty subjects with carotid artery intima-medial thickening (cases) and 40 subjects without thickening (control). Adiponectin levels in case group were lower than in control group, 4.1 $\mu \mathrm{g} / \mathrm{mL}$ (SB 1.7) and $6.0 \mu \mathrm{g} / \mathrm{mL}$ (SB 3.0), respectively. Statistical analysis with chi square test with confidence interval (Cl) $95 \%(1.05-12.78)$, OR 3.67 with $p=0.04(p<0.05)$ showed that adiponectin is a significant risk factor of carotid artery intima-medial thickening together with diabetes mellitus, hypertension, and metabolic syndrome.
\end{abstract}

Alamat Korespondensi:

dr. Hadi Juanda, SpPD.

Subbagian Kardiovaskular Bagian IImu Penyakit Dalam FK Unpad

RS. Dr. Hasan Sadikin Bandung. Jl. Pasteur No.38 Bandung 40161

Telp. (022) 2040926, 08122016670Email:juandahd@yahoo.com 
This study found the cut-off point of adiponectin was $5.09 \mathrm{ug} / \mathrm{dL}$ with ROC 0.682 , CI 95\% (0.569-0.782), sensitivity $77.5 \%$ and specificity $55,0 \%$. Conclusion: low adiponectin level $(<5,09 \mathrm{ug} / \mathrm{dL})$ is a risk factor of developing carotid artery intima-medial thickening.

Key words : Adiponectin, cardiovascular disease, CIMT

\section{PENDAHULUAN}

Penyakit kardiovaskular masih merupakan masalah kesehatan utama dan penyebab kematian utama di negara maju dan berkembang walaupun telah dilakukan upaya pencegahan dan tata laksana yang baik, di antaranya penyakit jantung koroner. Epidemi penyakit kardiovaskular ini terjadi selama abad ke-20. ${ }^{1}$

Jaringan lemak (adiposa) yang sebelumnya hanya dianggap sebagai deposit energi, kini terbukti mempunyai peran penting sebagai suatu organ endokrin dengan menghasilkan berbagai protein aktif yang disebut adipositokin atau adipokin, yang masing-masing mempunyai peran dalam homeostasis dan metabolisme tubuh. ${ }^{1-3}$ Salah satu di antara adipokin tersebut adalah adiponektin. Berbeda dengan adipositokin lainnya, kadar adiponektin berkurang pada keadaan obesitas dan berbanding terbalik dengan resistensi insulin, dislipidemia, dan sindrom metabolik (MetS). Makin banyak komponen MetS makin rendah kadar adiponektin..$^{3-6}$

Menurut penelitian, adiponektin mempunyai efek antiinflamasi dan antiaterogenik sehingga disimpulkan adiponektin bermanfaat karena mempunyai efek kardioprotektif. ${ }^{2,5}$ Walaupun demikian penelitian peran adiponektin pada manusia masih terbatas dan hasil penelitian menemukan hasil yang berbeda. Kumada dkk. ${ }^{7}$ menyimpulkan bahwa pada lakilaki dengan kadar adiponektin $<4 \mu \mathrm{gg} / \mathrm{mL}$ (berdasarkan kuartil terbawah), risiko penyakit jantung koroner (PJK) dua kali lipat lebih banyak (OR:2,051 $(95 \% \mathrm{Cl}, 1,288-4,951)$ ) independen terhadap faktor risiko PJK yang sudah dikenal. Hasil ini berbeda dengan penelitian Frystyk dkk. ${ }^{8}$ dan Sattar dkk. ${ }^{9}$ berturut-turut dalam penelitian prospektif dan meta-analisis yang menyimpulkan bahwa hubungan adiponektin dengan PJK relatif lemah (HR: 0,81; Cl: 0,66-0,99) dan (HR: 0,89; 95\% Cl:0,67-1,18).

Selain aksi adiponektin terhadap aterogenesis, adiponektin juga diketahui mampu berperan sebagai zat antitrombotik dan stabilisasi plak aterotrombotik sehingga menjelaskan hubungan kadar adiponektin dengan kejadian sindrom koroner akut (SKA). Nakamura dkk. ${ }^{5}$ menemukan kadar adiponektin lebih rendah berhubungan signifikan dengan kejadian infark miokardium, sehingga diharapkan intervensi meningkatkan kadar adiponektin bermanfaat untuk menurunkan risiko kejadian penyakit kardiovaskular. Di Indonesia penelitian yang dilakukan oleh Santoso dkk. ${ }^{10}$ menemukan bahwa hipoadiponektinemia secara signifikan berhubungan dan merupakan faktor risiko independen dengan kejadian infark miokardium.

Dari penelitian yang ada, diketahui bahwa CIMT dapat dijadikan surrogate adanya kerusakan/disfungsi pembuluh darah secara umum terutama pembuluh koroner jantung. CIMT menggambarkan keadaan disfungsi endotel yang terjadi pada pembuluh darah arteri karotis yang secara umum menggambarkan juga keadaan disfungsi endotel yang terjadi pada pembuluh darah lainnya, termasuk dalam hal ini disfungsi endotel yang terjadi pada arteri koroner dengan adanya kalsifikasi arteri koroner yang menandakan aterosklerosis dini. Semakin tebal CIMT, proses kalsifikasi pada arteri koroner semakin luas, juga disimpulkan bahwa semakin tebal CIMT maka semakin besar pula kemungkinan untuk terjadinya kejadian kardiovaskular di masa mendatang. ${ }^{11}$

Seberapa besar dan bagaimana peran adiponektin sebagai substrat yang bersifat protektif terhadap penyakit kardiovaskular masih memerlukan kajian lebih lanjut. Saat ini belum ada penelitian yang menghubungkan kadar adiponektin dengan penebalan tunika intima media arteri karotis di Indonesia. Berdasarkan hal-hal tersebut maka dilakukan penelitian untuk mengetahui peranan kadar adiponektin sebagai faktor risiko terjadinya penebalan tunika intima media arteri karotis pada pasien yang berobat jalan di RS Dr. Hasan Sadikin Bandung.

\section{METODE}

\section{Subjek Penelitian}

Subjek penelitian adalah penderita yang sudah ikut dalam penelitian lain yang melakukan pemeriksaan ketebalan tunika intima arteri karotis dengan USG (data sekunder). Kelompok kasus adalah penderita dengan penebalan tunika intima media arteri karotis yang berobat di Poli Penyakit Dalam RS Dr. Hasan Sadikin. Kelompok kontrol adalah penderita tanpa disertai penebalan tunika intima media arteri karotis yang berobat di Poli Penyakit Dalam RS Dr. Hasan Sadikin Bandung.

\section{Kriteria Inklusi}

Subjek adalah penderita obesitas abdominal pria dan wanita dengan rentang usia 40-59 tahun.

\section{Kriteria Eksklusi}

Termasuk kriteria eksklusi adalah gagal jantung kongestif, penyakit jantung koroner, stroke, dan 
Rancangan Penelitian

Untuk mengetahui peranan kadar adiponektin sebagai faktor risiko terhadap penebalan tunika intima media arteri karotis, maka penelitian dilakukan dengan rancangan penelitian kasus kelola (case control).

\section{Pengambilan Sampel}

Sampel diambil dari data penelitan sebelumnya yang melakukan pemeriksaan ketebalan tunika intima media arteri karotis dengan USG pada penderita obesitas abdominal yang berobat jalan di Poli Penyakit Dalam RS Dr. Hasan Sadikin, dan untuk kelompok kontrol dilakukan matching sesuai dengan kelompok kasus.

\section{Definisi Konsepsional Variabel}

Variabel bebas adalah kadar adiponektin serum, Variabel terikat adalah ketebalan tunika intima media arteri karotis, Variabel perancu adalah usia, merokok, kadar kolesterol LDL, DM, dan hipertensi

\section{Alur Penelitian}

Penelitian dilakukan setelah mendapat persetujuan dari Komite Etik Penelitian Kesehatan FK Unpad. Subjek penelitian adalah penderita yang memenuhi kriteria inklusi dan tidak termasuk kriteria eksklusi. Pada kelompok kasus dan kelompok kontrol akan diberikan penerangan mengenai penelitian yang dilakukan, baik keuntungan maupun kerugian yang mungkin timbul, jika setuju untuk mengikuti penelitian, penderita diminta menandatangani persetujuan (informed consent), kemudian dilakukan anamnesis tentang riwayat penyakit.

Hasil pemeriksaan berat badan, lingkar pinggang, tekanan darah, gula darah puasa, kadar kolesterol HDL, kadar kolesterol LDL, kadar trigliserida darah, dan hasil pemeriksaan USG tunika intima media arteri karotis diambil dari catatan medis penderita. Pemeriksaan kadar adiponektin menggunakan darah yang sebelumnya telah diambil untuk pemeriksaan profil lipid.

\section{Analisis Data}

Analisis yang pertama dilakukan adalah analisis univariat yang bertujuan menggambarkan karakteritik subjek penelitian. Selanjutnya dilakukan analisis bivariat yang bertujuan melihat hubungan antara kadar adiponektin dan ketebalan tunika intima media arteri karotis yaitu digunakan chi square test dengan jenis data kategorik untuk variabel kadar adiponektin maupun ketebalan tunika intima media arteri karotis serta ditentukan nilai Odds ratio (OR) pada $95 \%$ confident interval $(95 \% \mathrm{Cl})$ untuk melihat faktor risiko terjadinya penebalan tunika intima media arteri karotis.

Analisis untuk mengontrol atau mengendalikan variabel perancu serta menganalisis faktor risiko yang paling dominan terhadap terjadinya ketebalan tunika intima media arteri karotis dengan menggunakan analisis multivariat yaitu uji regresi logistik berganda (multiple logistic regression). Analisis data dilakukan dengan menggunakan program SPSS for windows versi 13.0 pada derajat kepercayaan $95 \%$ dengan nilai $p=0,05$.

\section{HASIL}

\section{Karakteristik Dasar Subjek Penelitian}

Subjek dan data penelitian diambil dari hasil penelitian bagian IImu Penyakit Dalam FK Unpad/RS dr. Hasan Sadikin pada penderita obesitas abdominal yang diperiksa ketebalan tunika intima media arteri karotis dengan USG yang dilakukan dari bulan Juli sampai dengan September 2008.

Dari data tersebut subjek penelitian dibagi menjadi dua kelompok yaitu penderita dengan penebalan tunika intima media arteri karotis (kelompok kasus) sejumlah 40 orang dan penderita tanpa penebalan tunika intima media arteri karotis (kelompok kontrol) sejumlah 40 orang. Dari 80 orang yang diikutsertakan pada penelitian ini didapatkan karakteristik dasar (Tabel 1).

Pada penelitian ini didapatkan perbedaan bermakna kadar adiponektin antara kedua kelompok, penderita dengan penebalan tunika intima media arteri karotis kadar adiponektin secara signifikan lebih rendah dibandingkan penderita tanpa penebalan tunika intima media arteri karotis, yaitu $4,1 \mu \mathrm{g} / \mathrm{mL}$ (SB 1,7) berbanding $6,0 \mu \mathrm{g} / \mathrm{mL}$ (SB 3,0). Hasil analisis statistik dengan uji Mann-Whitney menunjukkan bahwa terdapat perbedaan bermakna kadar adiponektin antara penderita dengan penebalan tunika intima media arteri karotis dibandingkan penderita tanpa penebalan tunika intima media arteri karotis $\mathrm{p}=0,003$ (Tabel 1 ).

Untuk mengetahui nilai titik potong (cutoff point) kadar adiponektin terhadap CIMT dilakukan analisis berdasarkan kurva ROC. Untuk mengetahui nilai titik potong kadar adiponektin terhadap CIMT dilakukan analisis berdasarkan kurva ROC. Dari kurva ROC diperoleh titik potong kadar adiponektin sebesar 5,09 ug/dL. Berdasarkan titik potong dapat dibuat tabel $2 \times 2$ seperti ditunjukkan pada Tabel 2. Berdasarkan Tabel 2 diperoleh besarnya sensitivitas $77,5 \%$, spesifisitas $55 \%$, dan akurasi $70,7 \%$. Terlihat bahwa kadar adiponektin memili-ki sensitivitas, spesifisitas, dan akurasi yang optimal terhadap CIMT.

Nilai cut-off point kadar adiponektin terhadap CIMT dapat dijelaskan pada Gambar. Hubungan Kadar Adiponektin dengan
Ketebalan Tunika Intima Media Arteri Karotis
Berdasarkan MetS, DM, Kadar Kolesterol 


\begin{tabular}{|c|c|c|c|}
\hline Variabel & $\begin{array}{c}\text { Kasus } \\
\mathrm{N}=40\end{array}$ & $\begin{array}{c}\text { Kontrol } \\
n=40\end{array}$ & $\mathbf{p}$ \\
\hline \multicolumn{4}{|l|}{ Usia (tahun) } \\
\hline Rata-rata & $49,9(5,6)$ & $49,4(5,2)$ & 0,649 \\
\hline Jenis kelamin & 1,000 & & \\
\hline Laki-laki $(n=38)$ & $18(50 \%)$ & $18(50 \%)$ & \\
\hline Perempuan $(n=6)$ & $22(50 \%)$ & $22(50 \%)$ & \\
\hline Lingkar pinggang $(\mathrm{cm})$ & $101,6(15,7)$ & $93,6(7,7)$ & 0,013 \\
\hline Indeks massa tubuh (IMT) (kgcm2) & $31,0(5,3)$ & $27,3(2,9)$ & 0,001 \\
\hline Merokok & 0,108 & & \\
\hline Ya (orang) & $19(47,5 \%)$ & $12(30 \%)$ & \\
\hline Tidak (orang) & $21(52,5 \%)$ & $28(70 \%)$ & \\
\hline \multicolumn{3}{|l|}{ MetS } & \multirow[t]{3}{*}{0,001} \\
\hline MetS & $32(80 \%)$ & $10(25 \%)$ & \\
\hline Non-MetS & $8(20 \%)$ & $30(75 \%)$ & \\
\hline Tekanan darah sistolik & $141,8(22,1)$ & $\begin{array}{l}120,9 \\
(16,6)\end{array}$ & 0,001 \\
\hline Tekanan darah diastolik & $88,5(8,9)$ & $79,3(8,5)$ & 0,001 \\
\hline Kadar trigliserida (mg/dL) & $232,6(152,8)$ & $\begin{array}{l}153,8 \\
(69,2)\end{array}$ & 0,004 \\
\hline Kadar kolesterol HDL (mg/dL) & $43,1(8,6)$ & $47,9(9,3)$ & 0,938 \\
\hline Kadar kolesterol LDL (mg/dL) & $151,6(41,7)$ & $\begin{array}{l}131,9 \\
(34,7)\end{array}$ & 0,04 \\
\hline Kadar gula darah puasa $(\mathrm{mg} / \mathrm{dL})$ & $110,6(35,6)$ & $98,4(42,9)$ & 0,004 \\
\hline Kadar adiponektin $(\mu \mathrm{g} / \mathrm{mL})$ & $4,1(1,7)$ & $6,0(3,0)$ & 0,003 \\
\hline
\end{tabular}

Tabel 2 Hubungan Antara Kadar Adiponektin dengan CIMT dan Nilai Cut-off Point Kadar Adiponektin Terhadap CIMT

\begin{tabular}{cccccccc}
\hline Variabel & $\begin{array}{c}\text { CIMT } \\
\text { Kasus }\end{array}$ & $\begin{array}{c}\text { CIMT } \\
\text { Kontrol }\end{array}$ & Se & Sp & Akurasi & P & $\begin{array}{c}\text { OR } \\
(95 \% \text { Cl })\end{array}$ \\
\hline $\begin{array}{c}\text { Adiponektin } \\
\text { Cut-off point }\end{array}$ & & & & & & & \\
$<5,09$ & 31 & 18 & $77,5 \%$ & $55 \%$ & $70,7 \%$ & 0,003 & 4,21 \\
$=5,09$ & 9 & 22 & & & & & $1,45-12,53$ \\
\hline
\end{tabular}

Keterangan: *) berdasarkan kurva ROC (Receiver Operating Characteristic)

Pada penderita MetS lebih banyak didapatkan penebalan tunika intima media arteri karotis yaitu sebesar 32 orang $(80 \%)$ dibandingkan penderita tanpa MetS yaitu sebesar 8 orang $(20 \%)$. Meski demikian hasil analisis statistik dengan uji Mantel-Haenszel pada derajat kepercayaan 95\% (0,90-11,28) menunjukkan tidak didapatkan perbedaan bermakna antara kedua kelompok dengan nilai $p=0,08$ (Tabel 3 ).

Pada penelitian ini didapatkan bahwa pada penderita dengan penebalan tunika intima media arteri karotis lebih banyak didapatkan kadar adiponektin lebih rendah dan DM dibandingkan dengan penderita tanpa penebalan tunika intima media arteri karotis. Hasil analisis statistik dengan uji MantelHaenszel pada derajat kepercayaan 95\% (1,18$10,92)$, OR 3,30 , dengan nilai $p=0,02$ menunjukkan bahwa adiponektin bersama DM secara bermakna merupakan faktor risiko untuk terjadinya penebalan tunika intima media arteri karotis (Tabel 3 ).

Pada penderita dengan penebalan tunika intima media arteri karotis didapatkan kadar adiponektin lebih rendah dan kadar kolesterol LDL lebih tinggi dibandingkan pada penderita tanpa penebalan tunika intima media arteri karotis. Hasil analisis statistik dengan uji Mantel-Haenszel pada derajat kepercayaan $95 \% \quad(1,47-13,12)$, OR 4,31 , dengan nilai $p=0,006$ menunjukkan bahwa adiponektin bersama kadar kolesterol LDL secara bermakna merupakan faktor risiko untuk terjadinya penebalan tunika intima media arteri karotis (Tabel 3).

Penderita dengan penebalan tunika intima media arteri karotis didapatkan kadar adiponektin lebih rendah dan hipertensi dibandingkan pada penderita tanpa penebalan tunika intima media arteri karotis. Hasil analisis statistik dengan uji Mantel-Haenszel pada derajat kepercayaan $95 \% \quad(1,83-25,47)$, OR 6,45 , dengan nilai $p=0,002$ menunjukkan bahwa adiponektin bersama hipertensi secara bermakna merupakan faktor risiko untuk terjadinya penebalan tunika intima media arteri karotis (Tabel 3). 


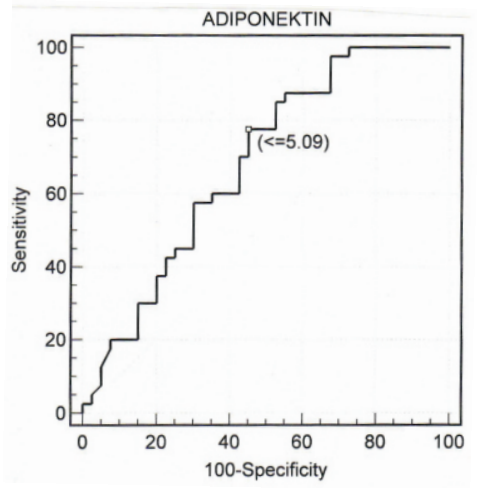

Gambar Titik Potong Adiponektin

Tabel 3 Hubungan Kadar Adiponektin dengan CIMT Berdasarkan MetS, DM, Kadar Kolesterol LDL, dan Hipertensi

\begin{tabular}{|c|c|c|c|c|c|}
\hline & & \multirow{2}{*}{$\begin{array}{c}\text { Kadar } \\
\text { adiponektin }\end{array}$} & \multicolumn{2}{|c|}{ CIMT } & \multirow[b]{2}{*}{ p } \\
\hline & & & Tebal & $\begin{array}{l}\text { Tidak } \\
\text { tebal }\end{array}$ & \\
\hline & Ya & $<5,09$ & 25 & 6 & \\
\hline \multirow[t]{4}{*}{ MetS } & & $\geq 5,09$ & 7 & 4 & 0,08 \\
\hline & Tidak & $<5,09$ & 6 & 12 & \\
\hline & & $\geq 5,09$ & 2 & 18 & \\
\hline & Ya & $<5,09$ & 16 & 3 & \\
\hline \multirow[t]{4}{*}{ DM } & & $\geq 5,09$ & 1 & 4 & 0,02 \\
\hline & Tidak & $<5,09$ & 15 & 15 & \\
\hline & & $\geq 5,09$ & 8 & 18 & \\
\hline & Ya & $<5,09$ & 20 & 13 & \\
\hline \multirow[t]{4}{*}{ LDL } & & $\geq 5,09$ & 5 & 12 & 0,006 \\
\hline & Tidak & $<5,09$ & 11 & 5 & \\
\hline & & $\geq 5,09$ & 4 & 10 & \\
\hline & Ya & $<5,09$ & 22 & 4 & \\
\hline \multirow[t]{3}{*}{ Hipertensi } & & $\geq 5,09$ & 5 & 7 & 0,002 \\
\hline & Tidak & $<5,09$ & 9 & 14 & \\
\hline & & $\geq 5,09$ & 2 & 17 & \\
\hline
\end{tabular}

Analisis Multivariabel Hubungan Adiponektin dengan Faktor Risiko Lain Terhadap Penebalan Tunika Intima Media Arteri Karotis

Untuk mengetahui hubungan kadar adiponektin dengan faktor risiko lain terhadap penebalan tunika intima media arteri karotis dilakukan analisis regresi logistik berganda, Adapun variabel yang masuk dalam analisis adalah variabel yang secara analisis bivariabel bermakna pada nilai $p<0,25$, variabel yang masuk dalam analisis adalah MetS $(p=0,001)$, hipertensi $(p=0,002)$, DM $(p=0,02)$, kadar kolesterol LDL $(p=0,006)$, dan merokok $(p=0,108)$.

Hasil analisis statistik dengan uji chi square pada derajat kepercayaan 95\% menunjukkan bahwa adiponektin bersama dengan MetS (OR 7,05; 95\% Cl 1,05-12,78) dan hipertensi (OR 6,46; 95\% Cl 1,97-21,20) secara bermakna merupakan faktor risiko untuk terjadinya penebalan tunika intima media arteri karotis. Hasil analisis multivariabel selengkapnya ditampilkan pada Tabel 4 .

\section{PEMBAHASAN}

Pada penelitian ini tidak didapatkan perbedaan bermakna pada kedua kelompok dalam hal usia, jenis kelamin, merokok, dan kadar kolesterol HDL. Usia pada kelompok kasus didapatkan lebih tua dengan rerata 49,9 (SB 5,6) tahun dibandingkan kelompok kontrol dengan rerata usia 49,4 (SB 5,2) tahun, tetapi dari hasil analisis statistik tidak didapatkan perbedaan bermakna, 
Tabel 4 Hasil Analisis Regresi Logistik Berganda Antara Berbagai Faktor Risiko dengan Ketebalan Tunika Intima Media Arteri Karotis

\begin{tabular}{lcccc}
\hline \multicolumn{1}{c}{ Variabel } & B & SE & Nilai $\mathbf{p}$ & OR (95\% Cl) \\
\hline Adiponektin & 1,299 & 0,637 & 0,04 & $3,67(1,05-12,78)$ \\
MetS & 1,953 & 0,598 & 0,001 & $7,05(2,18-22,80)$ \\
Hipertensi & 1,865 & 0,606 & 0,002 & $6,46(1,97-21,20)$ \\
Konstanta & & & $-2,754$ & \\
\hline
\end{tabular}

Tabel 5 Hubungan Faktor Risiko dengan Peluang CIMT

\begin{tabular}{clll}
\hline Hipertensi $(\mathbf{H T})$ & MetS & Adiponektin & Peluang \\
\hline Tidak & Tidak & Normal & 0,06 \\
Tidak & Tidak & Rendah & 0,189 \\
Tidak & MetS & Normal & 0,310 \\
Tidak & MetS & Rendah & 0,622 \\
HT & Tidak & Normal & 0,291 \\
HT & Tidak & Rendah & 0,601 \\
HT & MetS & Normal & 0,743 \\
HT & MetS & Rendah & 0,914 \\
\hline
\end{tabular}

dengan nilai $p=0,649$, hasil ini berbeda dengan yang didapatkan pada penelitian Lo $\mathrm{dkk}^{13}$ Berdasarkan jenis kelamin tidak didapatkan perbedaan bermakna secara statistik antara kedua kelompok dengan nilai $p=1,000$, hasil ini berbeda dengan yang didapatkan pada penelitian Oren $\mathrm{dkk} .{ }^{14}$ Pada kelompok kasus didapatkan proporsi merokok lebih besar dibandingkan kelompok kontrol, tetapi berdasarkan analisis statistik tidak didapatkan perbedaan bermakna dengan nilai $p=0,108$, hasil ini berbeda dengan yang didapatkan oleh penelitian Lo dkk. ${ }^{13}$ dan Oren dkk. ${ }^{14}$ Pada kelompok kasus didapatkan kadar kolesterol HDL yang lebih rendah dengan rerata 43,1 (SB $8,6) \mathrm{mg} / \mathrm{dL}$ dibandingkan kelompok kontrol dengan rerata $47,9(\mathrm{SB} 9,3) \mathrm{mg} / \mathrm{dL}$, tetapi dari hasil analisis statistik tidak didapatkan perbedaan bermakna dengan nilai $p=0,938$, hasil ini berbeda dengan yang didapatkan oleh penelitian Oren $\mathrm{dkk}^{14}$ Perbedaan hasil yang diperoleh pada penelitian ini kemungkinan disebabkan karena perbedaan ras/genetik subjek penelitian.

Pada penelitian ini didapatkan perbedaan bermakna pada kedua kelompok dalam hal ukuran lingkar pinggang, BMI, MetS, hipertensi, kadar trigliserida, kadar kolesterol LDL, dan kadar gula darah puasa.

Pada kelompok kasus didapatkan ukuran lingkar pinggang lebih besar dengan rerata 101,6 cm (SB 15,7) dibandingkan kelompok kontrol dengan rerata 93,6 cm (SB 7,7 ), secara statistik bermakna dengan nilai $p=0,013$. Hasil penelitian ini sesuai dengan hasil penelitian yang dilakukan oleh Oren dkk. ${ }^{14}$

Berdasarkan BMI didapatkan perbedaan bermakna secara statistik, pada kelompok kasus didapatkan ukuran BMI lebih besar dengan rerata 31,0 (SB 5,3) dibandingkan kelompok kontrol dengan rerata 27,3 (SB 2,9), dengan nilai $p=0,001$. Hasil penelitian ini sesuai dengan hasil penelitian yang dilakukan oleh Lo dkk. ${ }^{13}$ dan Oren dkk. ${ }^{14}$

Pada kelompok kasus didapatkan proporsi lebih banyak menderita MetS dibandingkan kelompok kontrol, hal ini bermakna secara statistik dengan nilai $p=0,001$, hasil ini sesuai dengan hasil penelitian Hassinen dkk. $^{12}$

Pada penderita dengan penebalan tunika intima media arteri karotis didapatkan proporsi lebih banyak menderita hipertensi dibandingkan kelompok kontrol, secara statistik bermakna dengan nilai $p=0,002$, hasil ini sesuai dengan penelitian Oren dkk. ${ }^{14}$ dan Lande dkk. ${ }^{15}$

Berdasarkan kadar trigliserida didapatkan perbedaan bermakna secara statistik, pada kelompok kasus didapatkan kadar trigliserida lebih tinggi dengan rerata 232,6 (SB 152,8) $\mathrm{mg} / \mathrm{dL}$ dibandingkan kelompok kontrol dengan rerata 153,8 (SB 69,2) $\mathrm{mg} / \mathrm{dL}$, dengan nilai $p=0,004$. Hasil penelitian ini sesuai dengan hasil penelitian Lo dkk. ${ }^{13}$ dan Oren dkk. ${ }^{15}$

Pada kelompok kasus didapatkan kadar kolesterol LDL lebih tinggi dengan rerata 151,6 (SB 41,7) $\mathrm{mg} / \mathrm{dL}$ dibandingkan kelompok kontrol dengan rerata 131,9 (SB 34,7) mg/dL, hasil ini berbeda makna secara statistik dengan nilai $p=0,04$. Hasil ini sesuai dengan hasil penelitan Oren $\mathrm{dkk}^{14}$

Berdasarkan kadar gula darah puasa didapatkan perbedaan bermakna, pada kelompok kasus didapatkan kadar gula darah puasa lebih tinggi dengan rerata 110,6 (SB 35,6) $\mathrm{mg} / \mathrm{dL}$ dibandingkan kelompok kontrol dengan rerata 98,4 (SB 42,9) $\mathrm{mg} / \mathrm{dL}$, dengan nilai $p=0,004$. Hasil penelitian ini sesuai dengan hasil 
penelitian Dullaart dkk. ${ }^{16}$

Pada penelitian ini dari hasil analisis regresi logistik berganda didapatkan perbedaan yang bermakna antara kedua kelompok dalam hal adiponektin, hipertensi, dan MetS. Hasil analisis statistik dengan uji chi square pada derajat kepercayaan 95\% menunjukkan bahwa adiponektin bersama dengan MetS (OR 7,05; $95 \% \mathrm{Cl} 1,05-12,78$ ) dan hipertensi (OR 6,46; $95 \% \mathrm{Cl} 1,97-21,20)$ secara bermakna merupakan faktor risiko untuk terjadinya penebalan tunika intima media arteri karotis, hasil ini sesuai dengan penelitian yang dilakukan oleh Hassinen $\mathrm{dkk}^{12}$ dan Tzou dkk. ${ }^{17}$ Kesimpulan: kadar adiponektin yang rendah $(<5,09 \mu \mathrm{g} / \mathrm{dL})$ berisiko lebih tinggi untuk terjadinya penebalan tunika intima media arteri karotis. Kadar adiponektin yang rendah bersama dengan hipertensi dan MetS merupakan faktor risiko untuk terjadinya penebalan tunika intima media arteri karotis.

\section{DAFTAR PUSTAKA}

1. Berg $\mathrm{AH}$, Scherer PE. Adipose tissue, inflammation, and cardiovascular disease. Circ Res. 2005;96:939-49.

2. Kadowaki T, Yamauchi T. Adiponectin and adiponectin receptors. Endoc Rev. 2005;26:439-51.

3. Standl E. Aetiology and consequences of the metabolic syndrome. Eur Heart J. 2005;7(Supplement):D10-3.

4. Chandran M, Phillips SA, Ciaraldi T, Henry RR. Adiponectin: more than just another fat cell hormone? Diabetes Care. 2003;26:2442-50.

5. Nakamura Y, Shimada K, Fukuda D, Shimada Y, Ehra S, Hirose M, dkk. Implications of plasma concentrations of adiponectin in patients with coronary artery disease. Heart. 2004;90:528-33.

6. Lau DCW, Dhillon B, Yan H, Szmitko PE, Verma S. Adipokines: molecular links between obesity and atheroslcerosis. Am J Physiol Heart Circ Physiol. 2005;288:2031-41.

7. Kumada M, Kihara S, Sumitsuji S, Kwamoto T, Matsumoto S, Ouchi N, dkk. Association of hypoadiponectinemia with coronary artery disease in men. Arterioscler Thromb Vasc Biol. 2003;23:85-9.
8. Frystyk J, Berne C, Berglund L, Jensevik K, Flyvbjerg A, Zethelius B. Serum adiponectin is a predictor of coronary heart disease: a population-based 10-year follow-up study in elderly men. J Clin Endocrinol Metab. 2007;92:571-6.

9. Sattar N, Wannamethee, Sarwar N, Tchernova J, Cherry L, Wallace AM, dkk. Adiponectin and coronary heart disease. A prospective study and meta-analysis. Circulation. 2006;114:6239.

10 . Santoso A, Wita W, Suastika K. Risk of acute myocardial infarction was associated with hypoadiponectinemia. Naskah Lengkap Pendidikan Kedokteran Berkelanjutan, Bagian IPD FK Unpad, Bandung 2007.

11 . Bots ML, Grobbee DE. Intima media thickness as a surrogate marker for generalized atherosclerosis. Cardiovascular Drug Ther. 2002; 16:341-51.

12 . Hassinen $M$, Komulainen $P$, Lakka TA, Vaisanen SB, Haapala I, Gylling H, dkk. Metabolic syndrome and the progression of carotid intima-media thickness in elderly women. Arch Intern Med. 2006;166:444-9.

13 . Lo J, Dolan SE, Kanter JR, Hemphill LC, Connelly JM, Lees RS, dkk. Effects of obesity, body composition, and adiponectin on carotid intima-media thickness in healty women. J Clin Endocrinol Metab. 2005;91(5):1677-82.

14 . Oren A, Vos LE, Uiterwaal CSPM, Gribbee DE, Bots ML. Cardiovascular risk factors and increased carotid intima-media thickness in healty young adults. Arch Intern Med. 2003:163:1787-92.

15 . Lande MB, Carson NL, Roy J, Meagher CC. Effects of childhood primary hypertension on carotid intima media thickness. Hypentension. 2006;48:40-4.

16 . Dullaart RPF, Vries R, Tol A, Sluiter WJ. Lower plasma adiponectin is a marker of increased intima-media thickness associated with type 2 diabetes mellitus and with male gender. Eur $\mathrm{J}$ Endocrinol. 2007;156:387-94.

17. Tzou WS, Douglas PS, Srinivasan SR, Bond MG, Tang $R$, Chen W, dkk. Increased subclinical atherosclerosis in young adults with metabolic syndrome. The Bogalusa Heart Study. Am College of Cardiol. 2005;46:457-63. 